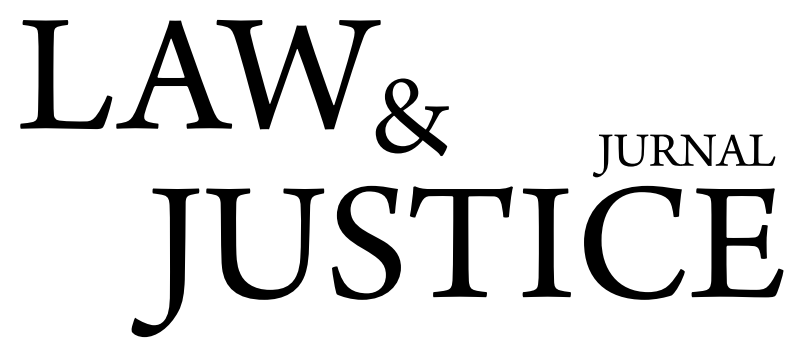

Volume 3, Nomor 1, April 2018

\title{
POLITIK HUKUM INDUSTRI KETENAGALISTRIKAN BERBASIS NILAI NILAI TRANSENDENTAL
}

\author{
Paryono \\ Mahasiswa Program Doktor (S-3) Ilmu Hukum (PDIH) \\ Universitas Muhammadiyah Surakarta \\ Jln. Ahmad Yani Tromol Pos 1 Pabelan Surakarta \\ Email : paryonotikas@gmail.com
}

\begin{abstract}
Abstrak
Infrastruktur Industri ketenagalistrikan sangat penting untuk pembangunan, karena daya saing internasional dan pertumbuhan ekonomi sangat di pengaruhi oleh keberadaan infrastruktur ketenagalistrikan. Kebijakan Politik hukum Industri ketenagalistrikan Indonesia saat ini sangat di pengaruhi peradaban barat yang bersendikan liberal mengikuti pasar bebas sebagai basis regulasi. Pandangan positivisme hukum peradaban barat yang liberal meletakan spiritual sebagai bagian terpisah dari satu kesatuan pembangunan hukum modern mempengaruhi produk hukum Industri ketenagalistrikan Indonesia menjadi liberal yang hanya bertujuan untuk kesejahteraan kelompok atau pemilik modal. Di negara Indonesia yang berideologi negara berke-Tuhanan Yang Maha Esa(sila pertama Pancasila) sudah seharusnya menjadikan hukum industri ketenagalistrikan berbasis nilai-nilai transendental, basis hukum nilai-nilai transendental memahami manusia dan kehidupannya dalam wujud yang utuh (holistik), sehingga di dapatkan hukum industri ketenagalistrikan yang membawa keadaan kesejahteraan manusia secara menyeluruh.
\end{abstract}

Kata Kunci: Politik hukum, Industri ketenagalistrikan, Transendental

\section{Pendahuluan}

Menentukan tatanan hukum yang akan di berlakukan di suatu negara merupakan kegiatan yang masuk dalam lingkup politik hukum ${ }^{1}$. Setiap tata hukum mencerminkan pandangan hidup tertentu yang dianut oleh kelompok masyarakat atau suatu bangsa tertentu. Tujuan hukum harus benar-benar untuk mensejahterakan masyarakat dalam kepentingan yang lebih besar, bukan untuk kepentingan mereka yang berkuasa.

Ideologi peradaban Barat yang lepas dari nilai-nilai agama, etik dan moral di suntikan oleh individuindividu, lembaga-lembaga konsultasi, perusahaan-perusahaan multinasional dan institusi-institusi ekonomi internasional kepada negara-negara klien mereka ${ }^{2}$. Kapitalisme industri energi listrik secara global diperankan oleh koorporasi multinasional atau transnasional. Dengan menjalankan operasinya

$1 \quad$ E.Sundari dan Endang Sumiarni, Politik Hukum Tata Hukum Indonesia, Yogyakarta: Cahaya Atma Pustaka, 2015, hlm.3

2 Dick Seed, Western Secularism, African Worldviews, and the Church, Western Secularism, African Worldviews, and the Church,: 76-87 http://journal.etsc.org, 2015. 
lebih ditekankan keseluruh negara-negara berkembang dengan jalan ikut mempengaruhi produk hukum ketenagalistrikan negara tersebut. Selanjutnya menanamkan investasi infrastruktur ketenagalistrikan ke negara tersebut dan kemudian menguasainya ${ }^{3}$.

Pemerintah Indonesia saat ini bergerak ke arah liberalisasi ${ }^{4} \mathrm{di}$ sektor industri energi listrik ${ }^{5}$. Kebijakan energi listrik yang diadopsi pada tahun 1989 bertujuan untuk memprivatisasi pasar listrik, untuk merestrukturisasi pasar dengan menciptakan entitas penyediaan, pembangkit, distribusi dan transmisi secara terpisah.

Liberalisasi ${ }^{6}$ bidang energi listrik ini disinyalir merupakan desakan pihak asing, maupun lembagalembaga international. Dengan alasan efisiensi lembaga tersebut mendorong liberalisasi sektor energi listrik kepada pemerintah. Pemerintah Indonesia pada saat ini sedang membangun pembangkit listrik mencapai 35000 Megawatt hingga 2019 program 35 ribu MW ini bertujuan untuk memenuhi kebutuhan listrik masyarakat Indonesia ${ }^{7}$.

\section{Pembahasan}

Ideologi peradaban Barat yang lepas dari nilai-nilai agama, etik dan moral disuntikan oleh individuindividu, lembaga-lembaga konsultasi, perusahaan-perusahaan multinasional dan institusi-institusi ekonomi internasional kepada negara-negara klien mereka ${ }^{8}$. Pasar Industri listrik telah menjadi arena sensitif yang terus-menerus menarik perhatian global dan membentuk agenda utama pada menu yang harus dilakukan oleh hampir semua pemerintah secara global. Karena ancaman yang ditimbulkannya terhadap keberlanjutan ekonomi nasional, maka pembangunan infrastruktur ketenagalistrikan sangat di galakkan dan karena hal ini pula pihak pemodal asing atau kapitalisme global sangat ingin berperan dalam pembangunan tersebut karena ingin menancapkan jaring jaring kekuatan dan untuk penghisapan keuntungan yang didapatkannya dengan awal mula mempengaruhi produk hukum industri ketenagalistrikan suatu negara9.

Proses globalisasi ditandai dengan pesatnya perkembangan paham kapitalisme, yakni kian terbuka dan mengglobalnya peran pasar, investasi, dan proses produksi dari perusahaan-perusahaan transnasiona ${ }^{10}$, yang kemudian dikuatkan oleh ideologi dan tata dunia perdagangan baru di bawah suatu aturan yang ditetapkan oleh organisasi perdagangan bebas secara global. Pendorong globalisasi adalah

3 Paryono, Perkembangan hukum Energi Ketenagalistrikan di Indonesia, Hukum Transendental Pengembangan dan Penegakan hukum di Indonesia, Genta Publishing, Yogyakarta, 2018, hlm.507

4 liberalisme telah mendominasi pemikiran politik normatif dan juga politik praktis di Barat selama enam puluh tahun terakhir, sampai pada titik di mana ia menjadi warisan bersama di antara teori politik, politisi profesional, dan hampir semua hal penting. gerakan politik di negara asalnya. Hal ini dibuktikan dengan fakta bahwa hampir tidak ada yang menentang kebebasan atau demokrasi lagi, yang merupakan nilai utama liberalism; Dag Einar Thorsen and Amund Lie, What is Neoliberalism?, Department of Political Science University of Oslo.

5 Indonesia telah berusaha untuk melakukan memprivatisasi utilitas sektor publik PLN sejak awal 2000an. Ada juga sejumlah IPP, banyak didirikan pada tahun 1990-an dengan kesepakatan korup yang memaksa PLN untuk membeli listrik dengan harga berlebih; David Hall, Sandra van Niekerk, Jenny Nguyen and Steve Thomas, Energy Liberalisation, privatisation and public ownership, Public Services International Research Unit (PSIRU).

6 Liberalisasi dimulai pada tahun 1980-an dengan penekanan pada 'privatisasi', namun perhatian tampaknya beralih ke reformasi peraturan di tahun 1990an, kebijakan privatisasi berpusat pada bentuk kepemilikan, dan khususnya mengenai pemindahan kepemilikan dari domain publik ke swasta; David Levi Faur, The Politics of Liberalisation: Privatisation and Regulation-Forcompetition in Europe's and Latin America's Telecoms and Electricity Industries, European Journal of Political Research 42: 705-740, 2003, University of Haifa, Israel and University of Oxford, UK.

7 http://listrik.org/pln/program-35000-mw/di akses tanggal 16-11-2017 pukul 10:00 WIB.

8 Dick Seed, Western Secularism, African Worldviews, and the Church, Western Secularism, African Worldviews, and the Church,: 76-87 http://journal.etsc.org, 2015.

9 Di undangkannya UU No.30 Tahun 2009 dan isi dari UU tersebut sangat kental pengaruhnya dari lembagakeuangan internasional.

10 Dunia sekarang bergerak cepat menuju pembangunan peradaban. Industri, pabrik, pembangkit listrik, berbagai lembaga pemerintah, lembaga ilmiah, organisasi swasta tumbuh berdasarkan sumber energi alam yang tersedia; Abu Md. Abdul Wadud, Md. Tousif Zaman, Fazlay Rabbee \& Md Rajibur Rahman, Renewable Energy: An Ideal Solution of Energy Crisis and Economic Development in Bangladesh., Global Journal of Researches in Engineering Electrical and Electronics Engineering Volume 13 Issue 15 Version 1.0 Year 2013 Type: Double Blind Peer Reviewed International Research Journal. 
ekspansi kapitalisme global yang menuntut bahwa tata perekonomian di seluruh dunia diserahkan kepada mekanisme pasar ${ }^{11}$. Globalisasi, sebagai bentuk baru ekspansi kapitalisme, akan bisa berlangsung baik apabila di kawasan manapun ditumbuhkan demokrasi ${ }^{12}$. Dengan demikian sisi positif dari globalisasi adalah bahwa globalisasi mempercepat proses demokratisasi di suatu negara dengan segala desakan yang ditimbulkannya.

Ilmu Modern yang selama ini berada dalam koridor hegemoni modernis-positivistic dengan doktrin empiris, objektivis, dan rasional mulai di gugat kaum pemikir transcendental yang lebih mengedepankan nilai dan makna di balik itu, sehingga tampak bangunan ilmu yang menjadi lebih terbuka dan utuh dalam merespon persoalan hidup dan kehidupan ${ }^{13}$. Interaksi antara hukum atau ilmu hukum dengan nilai-nilai spiritual, yang meliputi etika, moral, dan agama sangat di perlukan. Untuk mengkaji dan memahami hukum harus lebih menekankan hal yang sifatnya subtantif dan transcendental, dengan mendasarkan pada fakta sosial yang tidak lepas dari nilai-nilai agama, etik dan moral ${ }^{14}$.

\section{Liberalisasi dan Privatisasi Industri Energi Listrik.}

Proses globalisasi ${ }^{15}$ ditandai dengan pesatnya perkembangan paham kapitalisme, yakni kian terbuka dan mengglobalnya peran pasar, investasi, dan proses produksi dari perusahaan-perusahaan transnasiona ${ }^{16}$, yang kemudian dikuatkan oleh ideologi dan tata dunia perdagangan baru di bawah suatu aturan yang ditetapkan oleh organisasi perdagangan bebas secara global ${ }^{17}$. Pendorong globalisasi adalah ekspansi kapitalisme global yang menuntut bahwa tata perekonomian di seluruh dunia diserahkan kepada mekanisme pasar ${ }^{18}$. Tata kelola perdagangan dan bisnis dalam kacamata globalisasi sebagai suatu sistem diharapkan terdapat suatu kontrol mutlak dunia oleh kekuatan ekonomi supranasional melalui deregulasi pasar.

Pada awal 1990-an sebagian besar ekonomi memiliki rencana untuk memulai reformasi pasar di sektor listrik. Chili adalah negara pertama yang menerapkan model pada tahun 1982, diikuti oleh Inggris pada tahun 1990, Norwegia pada 1991 Swedia pada tahun 1994 dan Finlandia pada tahun 1996 ${ }^{19}$. Nasihat dan dukungan keuangan dari dana moneter internasional dan bank dunia, pemerintah suatu negara melakukan langkah-langkah restrukturisasi kelembagaan besar untuk mengatasi tantangantantangan ini $^{20}$,Ini menandakan bahwa liberalisasi pasar listrik nasional di Eropa sekarang lebih dekat

11 Etty R.Agoes, Peran Hukum dalam Pembangunan Indonesia: Kenyataan Harapan Tantangan,Remaja Rosdakarya, Bandung,2013,hlm :11

12 Fx. Adji Samekto, mengungkap relasi kapitalisme, demokrasi dan globalisasi (kajian dalam perspektif studi hukum kritis), fakultas hukum universitas diponegoro.

13 Absori,et,al (ed), Transendensi Hukum : Prospek dan Implementasinya, Yogyakarta: Genta Publishing,2016,hlm.93.

14 Absori, Hukum Dan Dimensi Spiritual : Perspektif Positivitis, Pospositivistis dan Spiritualisme', dalam Profetika, Jurnal Studi Islam, Vol.7,No.2, diterbitkan oleh Magister Pemikiran Islam, Program Pascasarjana, Universitas Muhammadiyah Surakarta,2005.

15 Globalisasi memberikan berbagai manfaat dan beberapa "aspek positif" bagi perusahaan, namun juga memiliki "aspek negatif" karena menyajikan risiko (ancaman), Isu mendasar globalisasi adalah dalam mempengaruhi perusahaan domestik, M. Şengül1, L. Alpkan2 \& E. Eren3, Effect of Globalization on the Operational Performance: A Survey on SMEs in the Turkish Electric Industry, International Business Research; Vol. 8, No. 7; 2015.

16 Dunia sekarang bergerak cepat menuju pembangunan peradaban. Industri, pabrik, pembangkit listrik, berbagai lembaga pemerintah, lembaga ilmiah, organisasi swasta tumbuh berdasarkan sumber energi alam yang tersedia; Abu Md. Abdul Wadud, Md. Tousif Zaman, Fazlay Rabbee \& Md Rajibur Rahman, Renewable Energy: An Ideal Solution of Energy Crisis and Economic Development in Bangladesh., Global Journal of Researches in Engineering Electrical and Electronics Engineering Volume 13 Issue 15 Version 1.0 Year 2013 Type: Double Blind Peer Reviewed International Research Journal.

17 Liberalisasi dimulai pada tahun 1980-an dengan penekanan pada 'privatisasi', namun perhatian tampaknya beralih ke reformasi peraturan di tahun 1990-an, kebijakan privatisasi berpusat pada bentuk kepemilikan, dan khususnya mengenai pemindahan kepemilikan dari domain publik ke swasta; David Levi-Faur, The politics of liberalisation: Privatisation and regulation-forcompetition in Europe's and Latin America's telecoms and electricity industries, European Journal of Political Research 42: 705-740, 2003.

18 Etty R.Agoes, Peran Hukum dalam Pembangunan Indonesia: Kenyataan Harapan Tantangan,Remaja Rosdakarya, Bandung,2013,hlm :11

19 Meyer, N. I. (2003). European schemes for promoting renewables in liberalised markets. Energy Policy, 31(7), $665-676$.

20 Joseph Mawejje1, Ezra Munyambonera1 \& Lawrence Bategeka, Powering Ahead: The Reform of the Electricity Sector in Uganda, Energy and Environment Research; Vol. 3, No. 2; 2013 ISSN 1927-0569 E-ISSN 1927-0577 Published by 
dengan tujuan jangka panjang dari pasar energi tunggal Eropa ${ }^{21}$. Liberalisasi sektor listrik adalah bagian dari kecenderungan yang lebih luas menuju liberalisasi dan penarikan negara dari keterlibatan dalam industri infrastruktur ketenagalistrikan.

Krisis listrik California dan pemadaman tahun 2003 di New York dan sebagian Eropa telah jelas mengurangi antusiasme politik untuk reformasi industry ketenagalistrikan ${ }^{22}$. Proses liberalisasi pasar energi di Eropa semakin terfokus pada integrasi pasar listrik dan isu-isu lintas batas terkait suatu wilayah. Ini menandakan bahwa liberalisasi pasar listrik nasional sekarang lebih dekat dengan tujuan jangka panjang dari pasar energi tunggal Eropa ${ }^{23}$. Privatisasi industri pasokan listrik Inggris pada tahun 1989/90 secara dramatis mengubah struktur sektor ini, yang telah berada di bawah kepemilikan publik sejak tahun 1947 ketika pemerintah Partai Buruh telah menasionalisasi lebih dari 570 badan publik dan swasta yang terlibat dalam pembangkitan dan distribusi listrik. UU Ketenagalistrikan tahun 1947 serta dua reorganisasi pada tahun 1955 dan 1957 mengarah pada pembentukan Dewan Pembangkit Listrik Sentral (CEGB) di Inggris dan Wales, yang memiliki hak monopoli atas pembangkit dan transmisi tenaga listrik. California mengalami pemadaman berskala besar selama krisis restrukturisasi listriknya pada 2000-2001 menggerakkan Pacific Gas \& Electric Co. menjadi bangkrut dan hampir bangkrut Southern California Edison, yang diselamatkan hanya oleh bailout dari negara mengakibatkan konsumen California membayar miliaran dolar lebih banyak. untuk listrik. Tidak mengherankan, California menunda eksperimennya dalam restrukturisasi utilitas listrik. Contoh restrukturisasi utilitas listrik yang menyebabkan negara seperti Virginia untuk mengatur ulang utilitas listrik mereka, ${ }^{24}$.empiris menunjukkan kegagalan Amerika Latin untuk menjadi seperti eropa 'Eropa' meskipun munculnya liberalisasi yang luas dan menyeluruh ${ }^{25}$

\section{Regulasi Indutri Ketenagalistrikan dalam hukum positif Indonesia.}

Pasar listrik telah menjadi arena sensitif yang terus-menerus menarik perhatian global dan membentuk agenda utama pada menu yang harus dilakukan oleh hampir semua pemerintah secara global. Ancaman yang ditimbulkannya terhadap keberlanjutan ekonomi nasional, pembangunan dan pertumbuhan yang cukup besar terlihat jelas dalam cara setiap negara di dunia mencari dan mengeksploitasi berbagai sumber energi alternatif untuk menghasilkan listrik dengan cara yang paling ekonomis .

Setelah krisis 1997, pemerintah Indonesia mengalami kesulitan keuangan yang memaksanya untuk mengurangi pengeluaran pembangunan, terutama untuk infrastruktur ketenagalistrikan dan dengan dalih itu pula infrastruktur ketenagalistrikan pihak swasta atau asing di ijinkan ikut berperan ${ }^{26}$.

Liberalisasi bidang energi listrik ini disinyalir merupakan desakan pihak asing, maupun lembagalembaga international. Dengan alasan efisiensi lembaga tersebut mendorong liberalisasi sektor energi

Canadian Center of Science and Education.

21 Tooraj Jamasb and Michael Pollitt, Electricity Market Reform in the European Union: Review of Progress toward Liberalization \& Integration, Reprint Series Number $201 *$ Reprinted from The Energy Journal, Vol. 26, Special Edition, pp. 11-41, 2005, The Energy Journal, European Energy Liberalisation Special Issue. Copyright (C2005 by the IAEE. The Energy Journal.

22 Hal ini terlepas dari fakta bahwa tampaknya ada sedikit bukti formal tentang hubungan antara reformasi listrik dan pemadaman listrik

23 Tooraj Jamasb and Michael Pollitt, Electricity Market Reform in the European Union: Review of Progress toward Liberalization \& Integration, Reprint Series Number 201 *Reprinted from The Energy Journal, Vol. 26, Special Edition, pp. 11-41, 2005, The Energy Journal, European Energy Liberalisation Special Issue. Copyright $@ 2005$ by the IAEE. The Energy Journal.

24 Eric L. Prentis, Evidence on U.S. Electricity Prices: Regulated Utility vs. Restructured States, International Journal of Energy Economics and Policy Vol. 5, No. 1, 2015, pp.253-262.

25 David Levi-Faur, The politics of liberalisation: Privatisation and regulation-forcompetition in Europe's and Latin America's telecoms and electricity industries, European Journal of Political Research 42: 705-740, 2003.

26 Peran serta swasta atau asing di Indonesia di implementasikan lebih banyak pada pembangkit listrik walaupun ada beberapa titik di tanah Indonesia yang dari pembangkit sampai distribusi di kuasai oleh swasta contohnya di cikarang listrindo sebuah pusat PLTGU berada di tengah daratan tidak di tepi pantai, di cikarang bekasi jawa barat dengan kekuatan sistem sampai saat ini total sekitar seribu MW. 
listrik kepada pemerintah ${ }^{27}$. Pemerintah Indonesia pada saat ini sedang membangun pembangkit listrik mencapai 35 ribu MW hingga 2019 program 35 ribu MW ini bertujuan untuk memenuhi kebutuhan listrik masyarakat Indonesia ${ }^{28}$.

Liberalisasi industri ketenagalistrikan akan menghasilkan oligarki baru di bidang industri ketenagalistrikan, pertanyaannya adalah apakah persaingan pada bisnis akan mengarah pada struktur pasar oligopolistik yang didirikan di tingkat suatu wilayah, dan apa yang akan menjadi karakteristik dari struktur yang efektif? Apa implikasinya bagi pelanggan akhir? Munculnya struktur yang efektif tergantung pada kemampuan untuk merealisasikan investasi ke kapasitas produksi baru dan infrastruktur jaringan. Itu harus memenuhi evolusi permintaan dalam kondisi harga demi kepentingan konsumen. "Kesulitannya adalah identifikasi secara alami dari struktur efektif ini. Mereka memungkinkan perusahaan untuk mengimplementasikan investasi koheren yang memungkinkan keseimbangan pasar. Kondisi ini dikenal dengan istilah gesekan atau ketidaksempurnaan pasar. Masalah bagi pihak berwenang yang bertanggung jawab atas persaingan dan regulasi adalah untuk mengetahui keseimbangan antara gesekan dan ketidaksempurnaan, Pada pembukaan UUD 45 di katakan bahwa tujuan pebentukan Negara Kesatuan Republik Indonesia adalah untuk melindungi segenap bangsa Indonesia dan seluruh tumpah darah Indonesia Pada pasal 33 ayat (2) UUD 45 yang lama maupun perubahan dikatakan bahwa: Cabang Produksi yang penting bagi Negara dan menguasai hajat hidup orang banyak harus di kuasai oleh negara dalam keputusan mahkamah konstitusi dikatakan bahwa dampak unbundling akan menghilangkan penguasaan negara atas Instalasi Listrik, dengan demikian terbukti dalam persidangan Mahkamah Konstitusi bahwa Listrik adalah meruapakan cabang produksi yang penting bagi negara dan meguasai hajat hidup orang banyak, untuk itu harus tetap di kuasai negara.

Melihat perkembangan perekonomian saat ini boleh disimpulkan bahwa filosofi Pancasila sudah tidak sepenuhnya diikuti, dan cenderung terjebak kedalam permainan kapitalis dalam jargon globalisasi dalam persidangan terakhir Mahkamah Konstitusi agustus 2004 menjelang di putuskannya perkara Judicial Review UU No.20 Tahun 2002 tentang Ketenagalistrikan, ditemukan bukti tambahan yang memperkuat alasan mengapa pemerintah Indonesia menerapkan liberalisasi sektor ketenagalistrikan sesuai undangundang tersebut, ternyata terdapat dokumen letter of intent (loi) yang terbit pada awal tahun 1998, pada butir 20 mengatakan tentang penerapan liberalisasi sektor ketenagalistrikan di Indonesia. Tahun 2002 pemerintah Indonesia dan DPR RI telah membuat UU No.20 Tahun 2002 tentang Ketenagalistrikan yang menggantikan UU No.15 Tahun 1985. Undang Undang ini dibikin sebagai penjabaran secara hukum dari kemauan politik pemerintah Indonesia atas sektor ketenagalistrikan. Tahun 2003-2004, UU No 20 tahun 2002 tentang Ketenagalistrikan ini diajukan gugatan Judicial Review ke Mahkamah Konstitusi oleh beberapa kalangan Civil Society. Pasca dibatalkannya undang undang tersebut, pemerintah kemudian membuat konsep baru undang undang ketenagalistrikan sebagai pengganti undang-undang No 20 Tahun 2002 yang dibatalkan dan lahirlah undang-undang No.30 Tahun 2009. Berdasarkan UU No. 30 Tahun 2009, penyediaan tenaga listrik dikuasai oleh negara yang penyelenggaraannya dilakukan oleh pemerintah dan pemerintah daerah berlandaskan prinsip otonomi daerah, yang dilaksanakan oleh BUMN dan BUMD. Namun demikian, badan usaha swasta atau asing, koperasi dan swadaya masyarakat dapat berpartisipasi dalam usaha penyediaan tenaga listrik tersebut.

27 Upaya pemerintah Indonesia untuk menyesuaikan diri dengan paradigma pro-pasar telah menggejala di tahun1980an. Dalam pembangunan PLTU Paiton I, corporate power dari pebisnis lokal memainkan peran signifikan dalam menjembatani ambisi ekspansi pelaku ekonomi asing dengan ambisi kekuasaan dari penguasa dalam sistem politik yang otoriter. Pelibatan kroni penguasa dalam aktivitas bisnis ini menjadi kunci bagi keberhasilan untuk memperoleh dukungan politik. Walaupun terdapat blue- print rencana privatisasi ini akan dilaksanakan secara gradual dan terencana, namun pelaksanaannya sangat tergantung dari kemauan penguasa yang memegang kekuasaan politik. Formulasi kebijakan keputusan privatisasi listrik di PLTU Paiton I dilaksanakan di dalam setting politik yang tidak demokratis dan otoriter. Suryo Utoro, Proses Formulasi Kebijakan Privatisasi Pembangunan Listrik Indonesia Pada Tahun 1980-an : Kasus Listrik Swasta Pltu Paiton I penelitian disertasi Univ Gajah Mada.

28 http://listrik.org/pln/program-35000-mw/di akses tanggal 16-11-2017 pukul 10:00 WIB. 
Privatisas $\mathrm{i}^{29}$ atau liberalisasi ${ }^{30}$ atas energi listrik bertentangan dengan cita proklamasi kemerdekaan Republik Indonesia dan Pasal 33 ayat (2) UUD 1945 dan perubahannya. Berdasarkan undang-undang ketenagalistrikan yang baru, PT PLN (BUMN) tidak lagi memegang monopoli penyediaan tenaga listrik di Indonesia dan tidak lagi berperan sebagai Pemegang Kuasa Usaha Ketenagalistrikan (PKUK) tetapi "hanya" sebagai Pemegang Ijin Usaha Kelistrikan Untuk Kepentingan Umum. Bila terjadi kelangkaan atau harga energi listrik tak terjangkau oleh daya beli masyarakat, maka hal ini akan ancaman yang serius bagi Negara Kesatuan Republik Indonesia dimasa yang akan datang. Dikatakan demikian karena hal tersebut akan dapat mengganggu jalannya pembangunan nasional yang berkelanjutan dan pada akhirnya nanti mengancam ketahanan nasional. Sumber daya energi diperlukan dalam rangka mendukung ketahanan nasional demi kelangsungan dan keberadaan negara.

Politik hukum Undang-Undang ketenagalistrikan Nasional seharusnya memperhatikan nilai-nilai yang tumbuh di Indonesia yaitu nilai-nilai relejius yang bersendikan ke-Tuhanan yang maha Esa seperti yang terdapat dalam sila kesatu pancasila dan Pembukaan UUD 1945 pada alenia 4 yaitu atas berkat rachmat Allah yang maha kuasa. bukan bersendikan liberal yang bebas dari wahyu atau agama sehingga tidak semestinya undang-undang industry ketenagalistrikan Indonesia berhaluan paham liberal. Liberalisasi di sector pembangkit listrik juga seharusnya di hindari karena tidak sesuai juga dengan konstitusi rupublik Indonesia pasal 33 ayat 2 UUD 1945 dan perubahannya menyatakan "cabang-cabang produksi yang penting bagi negara dan yang menguasai hajat hidup orang banyak di kuasai negara, menguasai di sini ya harus memiliki , dengan memiliki akan bisa menguasai dengan dengan arti sesungguhnya.

Teori hukum yang berpengaruh kuat terhadap konsep-konsep dan implementasi kehidupan hukum di Indonesia adalah teori hukum positivisme ${ }^{31}$. Pengaruh teori ini dapat dilihat dari dominannya konsep kodifikasi hukum dalam berbagai jenis hukum yang berlaku di Indonesia. Dengan sistem politik yang demikianlah berbagai produk politik yang berupa kebijakan dan peraturan perundang-undangan dilahirkan, termasuk undang-undang industri ketenagalistrikan.

Setiap tata hukum mencerminkan pandangan hidup tertentu yang dianut oleh kelompok masyarakat atau suatu bangsa tertentu. Oleh karenanya pandangan hidup ini menjadi dasar berlakunya dan menjadi penuntun arah perkembangan tata hukum. Industri ketenagalistrikan melibatkan hubungan internasional mengenai kebutuhan komponen dan kontrak kontrak kerjasama dengan bangsa lain yang menjalankan sebuah sistem yang kuat atas nama perusahaan, maka hal ini memerlukan sumberdaya manusia yang kompeten untuk mengelola hal tersebut baik dari sisi pengambil keputusan pembuat hukum maupun sumber daya manusia yang mengelola industri tersebut. Sumber daya manusia hukum industry ketenagalistrikan yang berideologi berke-Tuhanan yang Maha Esa sangat diperlukan dalam berhubungan dengan proses industri ketenagalistrikan di Indonesia.

\section{Regulasi Industri ketenagalistrikan dalam perspektif Islam sebagai akomodasi sila pertama Pancasila.}

Di Indonesia hukum yang berdimensi transsendental sesungguhnya mendapat apresiasi dan ruang baik pada aspek filosofis, konstitusional maupun sosiologis . Sejak kedatangan Islam pengaruh hukum Islam atau hukum yang berdimensi transendental itu cukup besar kepada masyarakat di Nusantara,

29 Pengalaman Nigeria sejauh ini dengan privatisasi menunjukkan bahwa hal tersebut memiliki konsekuensi negatif bagi orang-orang Nigeria. Beberapa konsekuensi negatif ini termasuk penghematan, karena pemerintah sendiri merupakan kontributor utama ketidakefisienan dari sektor listrik, Aminu, Isa Peterside, Zainab Brown, The Impact of Privatization of Power Sector in Nigeria: A Political Economy Approach, Mediterranean Journal of Social Sciences Mcser Publishing, Rome-Italy. Vol 5 No 26 November 2014.

30 Pemisahan segmen bisnis kelistrikan yang berbeda inilah yang dikenal sebagai unbundling, terinspirasi di seluruh dunia : contoh ;Margaret Thatcher di Inggris Raya pada akhir tahun 80an dan awal 90-an; Nnoli Kosisochukwu Pal1, Bolu Jones Ifeanyi, Obazenu Jesse Obaro, Deregulation of Electric Power in a Developing Economy: Prospects for Nigeria, International Research Journal of Engineering and Technology (IRJET), Volume: 03 Issue: 11- Nov -2016.

31 Positivisme hukum (aliran hukum positif), teori hukum yang memisahkan secara tegas antara hukum dan moral (antara hukum yang berlaku dan hukum, yang seterusnya, antara das sein dan das Sollen). Dalam kacamata positivis, tiada hukum lain kecuali perintah penguasa (law is a command of the lewgivers). Bahkan, bagian aliran hukum positif yang dikenal dengan nama legisme, berpendapat lebih tegas, bahwa hukum itu identik dengan undang-undang, Maskun, Filsafat Hukum : Teori dan Praktek, Prenada Media Group, Jakarta,2013 hlm:107, 
sebagai the living law, hukum Islam itu menjadi bagian dari kesadaran hukum rakyat yang tidak bisa di abaikan ${ }^{32}$. Rakyat pada jaman modern ini membutuhkan energi listrik sudah menjadi kebutuhan primer. Islam mengatur hal ini industry listrik ini sebagai kepemilikan negara, karena negara sebagai penanggung jawab kepentingan umum (mashalih al-ammah). Kaum muslimin berserikat (memiliki bersama) dalam tiga hal: air, padang rumput, dan api, tiga hal yang telah disebutkan itu tidak boleh dimonopoli oleh sebagian masyarakat karena tiga hal tersebut merupakan milik bersama seluruh kaum muslimin ${ }^{33}$. Hal ini menunjukan bahwa energi listrik dengan prasaranannya tidak boleh di monopoli oleh sebagian orang atau sekelompok pemodal dan harus di kuasai negara untuk di manfaatkan sebesar-besarnya untuk kemaslahatan umat, api di sini kita analogikan energi listrik, jadi negara harus memastikan agar bumi, api (energi listrik) dapat diakses oleh segenap warga manusia untuk kebutuhan hidupnya, sehingga segala cara dan usaha untuk memonopoli sumber-sumber kehidupan bagi orang banyak sekadar untuk memuaskan kepentingan pribadi ataupun sekelompok orang harus dapat dicegah oleh negara. Pada saat yang sama, dengan kekuasan yang ada di tangannya pemimpin negara berikut segenap aparat publik harus menjamin agar amanat Allah untuk menghantarkan anugerah-Nya sampai ke tangan segenap rakyatnya sesuai dengan kebutuhan, secara adil dan merata, Pada hal yang sama juga hal ini dalam mengelola industri ketenagalistrikan dengan kekuasaan penguasa yaitu negara Indonesia yang berkeTuhanan yang Maha Esa ini harus dapat menjamin amanat Allah untuk menghantarkan anugrahnya berupa energi listrik harus sampai ketangan segenap rakyatnya atau masyarakatnya.

Di dalam kitab al-Muwafaqat Asy-Syatibi menyatakan ${ }^{34}$ : Sesungguhnya hukum itu bertujuan mewujudkan kemaslahatan manusia di dunia dan akherat. Pengertian tersebut, dapat dikatakan bahwa tujuan politik hukum atau keberadaan hukum menurut As-Syatibi adalah untuk kesejahteraan umat manusia, Kemaslahatan, dalam hal ini diartikannya sebagai segala sesuatu yang menyangkut rezeki manusia, pemenuhan penghidupan manusia yang di jaman modern ini ini adalah kebutuhan energi listrik termasuk kebutuhan pokok manusia.

Abu Ishaq Asyi-Syatibi merumuskan lima tujuan hukum Islam, kelima tujuan hukum Islam tersebut di dalam kepustakaan disebut al-maqasid al khamsah atau al-maqasid al-shari'ah. Secara umum tujuan syariat Islam dalam menetapkan hukum-hukumnya adalah untuk kemaslahatan manusia seluruhnya, baik kemaslahatan di dunia maupun kemashlahatan di akhirat.

Konsep lima tujuan hukum Islam menurut As-Syatibi (al-Maqasid al-khamsah) yaitu memelihara harta (Hifdz Al-Maal) dengan memelihara harta negara yang berupa infrastruktur ketenagalistrikan dengan menjaga dari peneyerobotan pihak swasta atau asing yang dengan dalih privatisasi yang intinya ingin memindahkan aset negara berupa infrastruktur ketenagalistrikan atau memberikan lokasi investasi baru di bidang ketenagalistrikan khususnya pembangkitan listrik kepada pihak swasta atau asing. Negara untuk menjaga fungsinya yaitu memberikan kesejahteraan kepada masyarakatnya harus memelihara hal, baik dalam arti memiliki dan menguasai operasinya, hal ini demi memudahkan dalam usaha negara untuk menyejahterakan rakyatnya untuk masa sekarang dan masa depan dari eksistensi sebuah negara supaya tidak tersadra oleh kelompok pemodal lokal atau pemodal asing atau supaya negara bisa berdaulat tidak tersandra kepentingan kelompok kapitalisme global dalam bidang energi listrik yang turunannya pada kepentingan ekonomi yang selanjutnya berujung kepada kesejahteraan.

\section{Simpulan}

Pandangan positivisme hukum peradaban barat yang liberal meletakan spiritual sebagai bagian terpisah dari satu kesatuan pembangunan hukum modern mempengaruhi produk hukum Industri ketenagalistrikan Indonesia menjadi liberal yang hanya bertujuan untuk kesejahteraan kelompok atau pemilik modal. Di negara Indonesia yang berideologi negara berke-Tuhanan Yang Maha Esa(sila pertama Pancasila) sudah seharusnya menjadikan hukum industri ketenagalistrikan berbasis nilai-

32 Paryono, Paradigma Transendental Dalam Penegakan Hukum, Transendensi Hukum Prospek Dan Implementasi, Genta Publishing Cet.1, Yogyakarta, 2017, hlm.284

33 Abdullah Bin Shalih Al-Fauzan, Minhatul 'Alam Fi Syarhi Bulughul Maram, juz 6, Dar ibnil Jauzy KSA, hlm. 489-490.

34 Asy-Syatibi, al-Muwafaqat fi Usul al-Syari’ah, Beirut : Dar Al-Marefah, jilid-1, 1431, hlm 9. 
nilai transcendental. Kapitalisme industri energi listrik secara global diperankan oleh koorporasi multinasional atau trannasional. Dengan menjalankan operasinya lebih ditekankan keseluruh negaranegara berkembang dengan jalan ikut mempengaruhi produk hukum ketenagalistrikan negara tersebut. Sumber daya manusia dan politik produk hukum yang berke-Tuhanan yang Maha Esa sangat diperlukan dalam berhubungan dengan proses industri ketenagalistrikan di Indonesia, bukan sumber daya manusia yang berideologi liberal. Energi listrik dengan prasaranannya tidak boleh di monopoli oleh sebagian orang atau sekelompok pemodal dan harus di kuasai negara untuk di manfaatkan sebesar-besarnya untuk kesejahteraan rakyat.

\section{Daftar Pustaka}

Abdullah Bin Shalih Al-Fauzan, 1431,Minhatul 'Alam Fi Syarhi Bulughul Maram, juz 6, Dar ibnil Jauzy KSA, hlm. 489-490.

Absori, 2005, Hukum Dan Dimensi Spiritual : Perspektif Positivitis, Pospositivistis dan Spiritualisme', dalam Profetika, Jurnal Studi Islam, Vol.7,No.2, diterbitkan oleh Magister Pemikiran Islam, Program Pascasarjana, Universitas Muhammadiyah Surakarta.

Absori,, 2016, Transendensi Hukum : Prospek dan Implementasinya, Yogyakarta: Genta Publishing.

Abu Md. Abdul Wadud, Md. Tousif Zaman, Fazlay Rabbee \& Md Rajibur Rahman, Renewable Energy: An Ideal Solution of Energy Crisis and Economic Development in Bangladesh., Global Journal of Researches in Engineering Electrical and Electronics Engineering Volume 13 Issue 15 Version 1.0 Year 2013 Type: Double Blind Peer Reviewed International Research Journal.

Aminu, Isa Peterside, Zainab Brown, 2014, The Impact of Privatization of Power Sector in Nigeria: A Political Economy Approach, Mediterranean Journal of Social Sciences Mcser Publishing, Rome-Italy.

Asy-Syatibi, Al-Muwafaqat fi Usul al-Syari'ah, Beirut : Dar Al-Marefah, jilid-1.

Dag Einar Thorsen and Amund Lie, What is Neoliberalism?, Department of Political Science University of Oslo.

David Levi Faur, 2003, The Politics of Liberalisation: Privatisation and Regulation-Forcompetition in Europe's and Latin America's Telecoms and Electricity Industries, European Journal of Political Research 42: 705-740.University of Haifa, Israel and University of Oxford, UK. 